\title{
Pyridinolysis of Diethyl Phosphinic Chloride in Acetonitrile
}

\author{
Nilay Kumar Dey, Chan Kyung Kim,* and Hai Whang Lee* \\ Department of Chemistry, Inha University, Incheon 402-751, Korea. *E-mail: hwlee@inha.ac.kr \\ Received November 22, 2010, Accepted November 29, 2010
}

Key Words: Phosphoryl transfer reaction, Pyridinolysis, Diethyl phosphinic chloride, Concerted mechanism

\begin{abstract}
Nucleophilic substitution on $\mathrm{P}=\mathrm{O}$ (and $\mathrm{P}=\mathrm{S}$ ) center is not only important in biochemistry and is also extensive in synthesis and organometallic chemistry. The authors reported various types of phosphoryl transfer reactions to clarify the mechanism. ${ }^{1}$ Herein, the reactions of diethyl phosphinic chloride (2O) with substituted pyridines are investigated kinetically in acetonitrile at $45.0 \pm 0.1^{\circ} \mathrm{C}$ to gain further information of mechanism. The pyridinolyses of eleven $\mathrm{R}_{1} \mathrm{R}_{2} \mathrm{P}(=\mathrm{O}$ or $\mathrm{S})$ Cl-type substrates in $\mathrm{MeCN}$ (eq 1) are reviewed to obtain systematic information on phosphoryl transfer reaction mechanism. The kinetic results are discussed on the bases of thio effect on reactivity, steric effect of $R_{1}$ and $R_{2}$ on reactivity of substrate, electrophilicity of substrate, comparison between anilinolysis and pyridinolysis, and pyridinolysis mechanism. Eleven $\mathrm{R}_{1} \mathrm{R}_{2} \mathrm{P}(=\mathrm{O}$ or $\mathrm{S})$ Cl-type substrates are as follows: dimethyl phosphinic chloride (10); ${ }^{1 \mathrm{~h}}$ dimethyl thiophosphinic chloride (1S); ${ }^{\text {lh }}$ diethyl phosphinic chloride (2O); dimethyl chlorophosphate (3O) $;^{\text {1g }}$ dimethyl chlorothiophosphate (3S); ${ }^{1 \mathrm{~g}}$ diethyl chlorophosphate (4O) ${ }^{1 \mathrm{~g}}$ diethyl chlorothiophosphate (4S) ${ }^{1 \mathrm{lg}}$ diphenyl phosphinic chloride (5O); ${ }^{1 \mathrm{~d}}$ diphenyl thiophosphinic chloride $(\mathbf{5 S}) ;{ }^{\text {ld }} \mathrm{Y}$ - $O$-aryl phenyl phosphonochloridothioates (6S); ${ }^{\text {lf }} \mathrm{Y}$-aryl phenyl chlorophosphates (7O). ${ }^{\text {a }}$ The numbering of the substrates (1-7) follows the sequence of the size of the two ligands $\left(R_{1}+R_{2}\right)$, and $\mathbf{O}$ and $\mathbf{S}$ represent the $\mathrm{P}=\mathrm{O}$ and $\mathrm{P}=\mathrm{S}$ systems, respectively.
\end{abstract}

$$
\begin{array}{r}
\mathrm{R}_{1} \mathrm{R}_{2} \mathrm{P}(=\mathrm{O} \text { or } \mathrm{S}) \mathrm{Cl}+\underset{\mathrm{XC}_{5} \mathrm{H}_{4} \mathrm{~N}}{\stackrel{\mathrm{MeCN}}{\longrightarrow}} \\
\mathrm{R}_{1} \mathrm{R}_{2} \mathrm{P}(=\mathrm{O} \text { or } \mathrm{S}) \stackrel{+}{\mathrm{NC}_{5}} \mathrm{H}_{4} \mathrm{X}+\overline{\mathrm{Cl}}
\end{array}
$$

$\left(\mathrm{CH}_{3}\right)_{2} \mathrm{P}(=\mathrm{O}) \mathrm{Cl}(\mathbf{1 O}) ;\left(\mathrm{CH}_{3}\right)_{2} \mathrm{P}(=\mathrm{S}) \mathrm{Cl}(\mathbf{1 S}) ;\left(\mathrm{C}_{2} \mathrm{H}_{5}\right)_{2} \mathrm{P}(=\mathrm{O}) \mathrm{Cl}$ (2O); $\left(\mathrm{CH}_{3} \mathrm{O}\right)_{2} \mathrm{P}(=\mathrm{O}) \mathrm{Cl}(\mathbf{3 O}) ;\left(\mathrm{CH}_{3} \mathrm{O}\right)_{2} \mathrm{P}(=\mathrm{S}) \mathrm{Cl}(\mathbf{3 S}) ;\left(\mathrm{C}_{2} \mathrm{H}_{5} \mathrm{O}\right)_{2}$ $\mathrm{P}(=\mathrm{O}) \mathrm{Cl}(\mathbf{4 O}) ;\left(\mathrm{C}_{2} \mathrm{H}_{5} \mathrm{O}\right)_{2} \mathrm{P}(=\mathrm{S}) \mathrm{Cl}(\mathbf{4 S}) ;\left(\mathrm{C}_{6} \mathrm{H}_{5}\right)_{2} \mathrm{P}(=\mathrm{O}) \mathrm{Cl}(\mathbf{5 O})$; $\left(\mathrm{C}_{6} \mathrm{H}_{5}\right)_{2} \mathrm{P}(=\mathrm{S}) \mathrm{Cl}(\mathbf{5 S}) ;\left(\mathrm{YC}_{6} \mathrm{H}_{4} \mathrm{O}\right)\left(\mathrm{C}_{6} \mathrm{H}_{5}\right) \mathrm{P}(=\mathrm{S}) \mathrm{Cl}(\mathbf{6 S}) ;\left(\mathrm{YC}_{6} \mathrm{H}_{4} \mathrm{O}\right)$ $\left(\mathrm{C}_{6} \mathrm{H}_{5} \mathrm{O}\right) \mathrm{P}(=\mathrm{O}) \mathrm{Cl}(\mathbf{7 O})$

The observed pseudo-first-order rate constants $\left(k_{\text {obsd }}\right)$ were found to follow eq 2 for all of the reactions under pseudo-firstorder conditions with a large excess of pyridine nucleophile. The $k_{0}$ values were negligible $\left(k_{0}=0\right)$ in MeCN. The secondorder rate constants $\left(k_{2}\right)$ were determined for at least five con- centrations of anilines. The linear plots of eq 2 suggest that there is no base-catalysis or noticeable side reactions and that the overall reaction is described by eq 1 .

$$
k_{\text {obsd }}=k_{0}+k_{2}\left[\mathrm{XC}_{5} \mathrm{H}_{4} \mathrm{~N}\right]
$$

The $k_{2}$ values are summarized in Table 1 . The substituent effects of the nucleophiles upon the pyridinolysis rates correlate with those for a typical nucleophilic substitution reaction with negative $\rho_{\mathrm{X}}$ and positive $\beta_{\mathrm{X}}$ value. The Brönsted $\beta_{\mathrm{X}}$ value was obtained by correlating $\log k_{2}(\mathrm{MeCN})$ with $\mathrm{p} K_{\mathrm{a}}\left(\mathrm{H}_{2} \mathrm{O}\right),{ }^{2}$ which was justified theoretically and experimentally. ${ }^{3}$ Both the Hammett $\left(\log k_{2} v s \sigma_{\mathrm{X}}\right)$ and Brönsted $\left[\log k_{2} v s \mathrm{p} K_{\mathrm{a}}(\mathrm{X})\right]$ plots are linear with $\rho_{\mathrm{X}}=-2.52 \pm 0.08(\mathrm{r}=0.996)$ and $\beta_{\mathrm{X}}=0.45 \pm 0.02$ $(\mathrm{r}=0.994)$.

Table 2 shows the summations of inductive effects of the two ligands $\left[\sum \sigma_{\mathrm{I}}=\sigma_{\mathrm{I}}\left(\mathrm{R}_{1}\right)+\sigma_{\mathrm{I}}\left(\mathrm{R}_{2}\right)\right]{ }^{4}$ natural bond order $(\mathrm{NBO})$ charges on the $\mathrm{P}$ atom reaction center in the gas phase [B3LYP/ $6-311+\mathrm{G}(\mathrm{d}, \mathrm{p})$ level of theory], ${ }^{1 \mathrm{n}}$ summations of steric parameters of the two ligands $\left[\sum E_{\mathrm{S}}=E_{\mathrm{S}}\left(\mathrm{R}_{1}\right)+E_{\mathrm{S}}\left(\mathrm{R}_{2}\right)\right]$, ${ }^{5}$ second-order rate constants $\left(k_{2}\right)$ at $35.0{ }^{\circ} \mathrm{C}$, and Brönsted coefficients $\left(\beta_{\mathrm{X}}\right)$ and cross-interaction constants $\left(\mathrm{CICs} ; \rho_{\mathrm{XY}}\right)^{6}$ for the pyridinolyses of eleven $\mathrm{R}_{1} \mathrm{R}_{2} \mathrm{P}(=\mathrm{L}) \mathrm{Cl}$-type in $\mathrm{MeCN}$. The arrangement of the substrates in the column for $\mathrm{P}=\mathrm{O}(\mathbf{1 0}-\mathbf{7 O})$ and $\mathrm{P}=\mathrm{S}(\mathbf{1 S}-\mathbf{6 S})$ systems follows the sequence of the degree of steric hindrance (i.e., bulkiness) of the two ligands.

The $\mathrm{P}=\mathrm{O}$ systems are more reactive than their $\mathrm{P}=\mathrm{S}$ counterparts for several reasons, the so-called 'thio effect' which is mainly the electronegativity difference between $\mathrm{O}$ and $\mathrm{S}$ that favors $\mathrm{O}$ over $\mathrm{S}{ }^{7}$ The NBO charges on the $\mathrm{P}$ atom of $\mathrm{P}=\mathrm{O}$ systems are greater $(c a .0 .5-0.6)$ than those of their $\mathrm{P}=\mathrm{S}$ counterparts, implying the electronegativity difference between $\mathrm{O}$ and $\mathrm{S}$. Herein, the pyridinolysis rate ratios of $\mathrm{P}=\mathrm{O}$ and their $\mathrm{P}=\mathrm{S}$ counterparts of $\mathrm{R}_{1} \mathrm{R}_{2} \mathrm{P}(=\mathrm{O}$ or $\mathrm{S}) \mathrm{Cl}$ type in $\mathrm{MeCN}$ at $35.0{ }^{\circ} \mathrm{C}$ are great as follows: $k_{2}(\mathbf{1 O}) / k_{2}(\mathbf{1 S})=137,000 ; k_{2}(\mathbf{3 O}) / k_{2}(\mathbf{3 S})=$ $42 ; k_{2}(\mathbf{4 O}) / k_{2}(\mathbf{4 S})=44 ; k_{2}(\mathbf{5 O}) / k_{2}(\mathbf{5 S})=30$. The correlation $\sum \sigma_{\mathrm{I}}$ with the NBO charge on the $\mathrm{P}$ atom reaction center is roughly linear. The plots of the NBO charge on $\mathrm{P}$ against $\sum \sigma_{\mathrm{I}}$ yield the slopes of $0.622(\mathrm{r}=0.946)$ and $0.846(\mathrm{r}=0.918)$ for $\mathrm{P}=\mathrm{O}$ and

\begin{tabular}{|c|c|c|c|c|c|c|c|c|c|c|c|}
\hline $\mathrm{X}$ & 4-MeO & 4-Me & 3-Me & $\mathrm{H}$ & 3-Ph & 3-MeO & $3-\mathrm{Cl}$ & $3-A c$ & 4-Ac & $3-\mathrm{CN}$ & $4-\mathrm{CN}$ \\
\hline 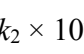 & $1+2$ & $0+$ & 1 & $8+$ & 0 & $29 \pm$ & + & $4 \pm$ & $7+$ & \pm & $498 \pm 0.019$ \\
\hline
\end{tabular}
$\mathrm{P}=\mathrm{S}$ systems, respectively. The sequence of the second-order

Table 1. Second-Order Rate Constants $\left(k_{2} \times 10^{2} / \mathrm{M}^{-1} \mathrm{~s}^{-1}\right)$ of the Reactions of $\mathrm{Et}_{2} \mathrm{P}(=\mathrm{O}) \mathrm{Cl}(\mathbf{2 O})$ with $\mathrm{XC}_{5} \mathrm{H}_{4} \mathrm{~N}$ in $\mathrm{MeCN}$ at $45.0{ }^{\circ} \mathrm{C}$ 
Table 2. Summary of Summations of Inductive Effects of the Two Ligands $\left(\sum \sigma_{\mathrm{I}}\right)$, NBO Charges on Reaction Center P, Summations of Steric Parameters of the Two Ligands $\left(\sum E_{\mathrm{S}}\right)$, Second-Order Rate Constants $\left(k_{2}\right)$ at $35.0{ }^{\circ} \mathrm{C}$, and Selectivity Parameters $\left(\beta_{\mathrm{X}}\right.$ and $\left.\rho_{\mathrm{XY}}\right)$ for the Pyridinolyses of Eleven $\mathrm{R}_{1} \mathrm{R}_{2} \mathrm{P}(=\mathrm{O}$ or $\mathrm{S}) \mathrm{Cl}$-type in $\mathrm{MeCN}$

\begin{tabular}{cccccccccc}
\hline sub. & $\mathrm{R}_{1}$ & $\mathrm{R}_{2}$ & $\sum \sigma_{\mathrm{I}}$ & charge on $\mathrm{P}$ & $-\sum E_{\mathrm{S}}$ & $k_{2} \times 10^{3 a}$ & $\beta_{\mathrm{X}}$ & $\rho_{\mathrm{XY}}$ & ref. \\
\hline $\mathbf{1 O}$ & $\mathrm{Me}$ & $\mathrm{Me}$ & -0.02 & 1.793 & 0.00 & $102,000^{b}$ & $0.17^{g} /-0.03^{h}$ & - & $1 \mathrm{~h}$ \\
$\mathbf{2 O}$ & $\mathrm{Et}$ & $\mathrm{Et}$ & -0.02 & 1.817 & 0.14 & $127^{c}$ & 0.45 & - & this work \\
$\mathbf{3 O}$ & $\mathrm{MeO}$ & $\mathrm{MeO}$ & 0.60 & 2.226 & - & 64.7 & 0.63 & - & $1 \mathrm{~g}$ \\
$\mathbf{4 O}$ & $\mathrm{EtO}$ & $\mathrm{EtO}$ & 0.56 & 2.236 & - & 52.8 & 0.73 & - & $1 \mathrm{~g}$ \\
$\mathbf{5 O}$ & $\mathrm{Ph}$ & $\mathrm{Ph}$ & 0.24 & 1.844 & 4.96 & 54.6 & 0.68 & - & $1 \mathrm{~d}$ \\
$\mathbf{7 O}$ & $\mathrm{YC}_{6} \mathrm{H}_{4} \mathrm{O}$ & $\mathrm{PhO}$ & 0.80 & 2.230 & - & $266^{d}$ & $0.16-0.18$ & -0.15 & $1 \mathrm{a}$ \\
$\mathbf{1 S}$ & $\mathrm{Me}$ & $\mathrm{Me}$ & -0.02 & 1.180 & 0.00 & 0.744 & $0.97^{i} / 0.27^{j}$ & - & $1 \mathrm{~h}$ \\
$\mathbf{3 S}$ & $\mathrm{MeO}$ & $\mathrm{MeO}$ & 0.60 & 1.687 & - & $1.54^{e}$ & $1.09^{g} / 0.20^{h}$ & - & $1 \mathrm{~g}$ \\
$\mathbf{4 S}$ & $\mathrm{EtO}$ & $\mathrm{EtO}$ & 0.56 & 1.701 & - & $1.19^{f}$ & $1.02^{g} / 0.29^{h}$ & - & $1 \mathrm{~g}$ \\
$\mathbf{5 S}$ & $\mathrm{Ph}$ & $\mathrm{Ph}$ & 0.24 & 1.236 & 4.96 & 1.83 & $1.53^{g} / 0.38^{h}$ & - & $1 \mathrm{~d}$ \\
$\mathbf{6 S}$ & $\mathrm{YC}_{6} \mathrm{H}_{4} \mathrm{O}$ & $\mathrm{Ph}$ & 0.52 & 1.462 & - & 11.4 & $0.87-0.95$ & -0.46 & $1 \mathrm{f}$ \\
\hline
\end{tabular}

${ }^{a}$ For the reactions of $\mathrm{X}=\mathrm{H}$ in nucleophiles, and $\mathrm{Y}=\mathrm{H}$ in substrates (for $\mathbf{7 O}$ and $\mathbf{6 S}$ ) at $35.0^{\circ} \mathrm{C}$. ${ }^{b}$ Extrapolated value in the Arrhenius plot with kinetic data: $k_{2}=34,300,40,400$, and $53,900 \times 10^{-3} \mathrm{M}^{-1} \mathrm{~s}^{-1}$ at $-25.0,-15.0$, and $-5.0^{\circ} \mathrm{C}$, respectively. ${ }^{\circ}$ Experimental value. ${ }^{d}$ Extrapolated value in the Arrhenius plot with kinetic data: $k_{2}=37.1,94.0$, and $135 \times 10^{-3} \mathrm{M}^{-1} \mathrm{~s}^{-1}$ at 5.0,15.0, and $25.0^{\circ} \mathrm{C}$, respectively. ${ }^{e}$ Extrapolated value in the Arrhenius plot with kinetic data: $k_{2}=2.23,3.27$, and $4.53 \times 10^{-3} \mathrm{M}^{-1} \mathrm{~s}^{-1}$ at $45.0,55.0$, and $65.0^{\circ} \mathrm{C}$, respectively. ${ }^{\prime}$ Extrapolated value in the Arrhenius plot with kinetic data: $k_{2}=1.70$, 2.36, and 3.11 $\times 10^{-3} \mathrm{M}^{-1} \mathrm{~s}^{-1}$ at 45.0, 55.0, and $65.0^{\circ} \mathrm{C}$, respectively. ${ }^{g} \mathrm{For} \mathrm{X}=4-\mathrm{MeO}, 4-\mathrm{Me}, 3-\mathrm{Me}, \mathrm{H}$, and 3-Ph. ${ }^{h} \mathrm{For} \mathrm{X}=3-\mathrm{MeO}, 3-\mathrm{Cl}, 3-\mathrm{Ac}, 4-\mathrm{Ac}$, 3-CN, and 4-CN. ${ }^{i}$ For $\mathrm{X}=4-\mathrm{MeO}, 4-\mathrm{Me}, 3-\mathrm{Me}$, and $\mathrm{H} .{ }^{j} \mathrm{For} \mathrm{X}=\mathrm{H}$, 3-Ph, 3-MeO, 3-Cl, 3-Ac, 4-Ac, 3-CN, and 4-CN.

rate constants of the pyridinolyses for both the $\mathrm{P}=\mathrm{O}$ and $\mathrm{P}=\mathrm{S}$ systems does not show systematic consistency with $\sum \sigma_{\mathrm{I}}, \mathrm{NBO}$ charge on $\mathrm{P}$, or even $\sum E_{\mathrm{S}}$. These results indicate that the pyridinolysis rates of $\mathrm{R}_{1} \mathrm{R}_{2} \mathrm{P}(=\mathrm{L}) \mathrm{Cl}$ in $\mathrm{MeCN}$ are not dependent upon one dominant factor but on many factors.

The pyridinolyses of $\mathbf{1 0}, \mathbf{1 S}, \mathbf{3 S}, \mathbf{4 S}$, and $\mathbf{5 S}$ yield biphasic concave upward free energy correlation (Hammett and Brönsted plots) for substituent $X$ variations with greater and smaller magnitudes of slopes for weakly and strongly basic nucleophiles, respectively. ${ }^{8}$ The authors proposed a concerted mechanism with a dominant backside nucleophilic attack towards the $\mathrm{Cl}$ leaving group (TSb) for weakly basic pyridines, and a concerted mechanism with a dominant frontside nucleophilic attack (TSf) for strongly basic pyridines, in which the pyridine and $\mathrm{Cl}$ occupy adjacent spaces in the TS, on the basis of the concave upward Brönsted plots with smaller $\beta_{\mathrm{X}}$ values for weakly basic pyridines and greater values for strongly basic pyridines.

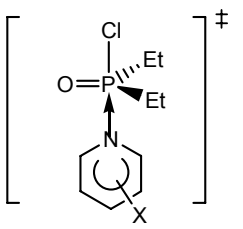

$\mathrm{TSb}$

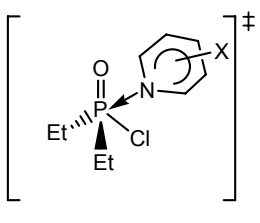

TSf
The greater $\beta_{\mathrm{X}}$ value for the more basic pyridines suggests a dominant frontside attack with greater bond formation compared to a dominant backside attack for the less basic pyridines. It is well known that a weakly basic group has a greater apicophilicity so that an apical approach is favored for such nucleophiles. ${ }^{1 b, 9}$ Since apical bonds are longer than equatorial bonds, ${ }^{1 b 9 a}$ apical nucleophilic attack should lead to a looser P-N bond in the TBP-5C TS structure and hence a smaller magnitude of $\beta_{\mathrm{X}}$ is obtained, while the equatorial attack should lead to tighter P-N bond in the TBP-5C TS, resulting in a larger magni- tude of $\beta_{\mathrm{X}}{ }^{1 \mathrm{~b}}$ Biphasic concave upward Hammett and Brönsted plots for substituent $\mathrm{X}$ variations in the nucleophiles of the reactions of $\mathrm{Y}$-aryl phenyl isothiocyanophosphate with X-pyridines in $\mathrm{MeCN}$ was also interpreted as a change in the nucleophilic attacking direction from dominant backside for less basic pyridines $\left(\beta_{\mathrm{X}}=0.12-0.15\right)$ to dominant frontside for more basic pyridines $\left(\beta_{\mathrm{X}}=1.13-1.28\right) .{ }^{\mathrm{lc}}$ It is the suggestion of the authors that the concave upward Hammett and Brönsted plots can also be diagnostic of a change in the attacking direction of the nucleophile depending on the substituents from backside to frontside.

The $\mathrm{S}_{\mathrm{N}} 2$ reaction mechanisms were proposed for the pyridinolyses of both 70 and $6 \mathrm{~S}$ on the basis of the negative sign of the CIC, $\rho_{\mathrm{XY}}{ }^{6}$ A relatively small degree of bond formation in the early TS could be proposed for $\mathbf{7 0}$ on the basis of the small magnitudes of $\rho_{\mathrm{XY}}$ and $\beta_{\mathrm{X}}$, ${ }^{1 \mathrm{a}}$ while a relatively large degree of bond formation in the TS could be proposed for $\mathbf{6 S}$ on the basis of the large magnitudes of $\rho_{\mathrm{XY}}$ and $\beta_{\mathrm{X}}$. ${ }^{\text {If }}$

In the pyridinolysis of $30\left(\beta_{\mathrm{X}}=0.63\right), 40\left(\beta_{\mathrm{X}}=0.73\right)$, and 50 $\left(\beta_{\mathrm{X}}=0.68\right)$, the authors proposed a concerted mechanism with both frontside and backside attacks, and the fraction of a frontside attack is more or less larger than that of a backside attack, on the basis of the magnitudes of $\beta_{\mathrm{X}}$ values. Taking into account $\beta_{\mathrm{X}}=0.17$ of 10 for weakly basic pyridines where the reaction proceeds through frontside nucleophilic attack, the authors propose a concerted mechanism with greater fraction of a frontside attack than that of a backside attack for the pyridinolysis of 20 with $\beta_{\mathrm{X}}=0.445$. Both front and backside nucleophilic attack were observed in the anilinolyses of some $\mathrm{R}_{1} \mathrm{R}_{2} \mathrm{P}(=\mathrm{L})$ Cl-type in $\mathrm{MeCN}$. ${ }^{\text {lct }}$

As seen in Table 3, predominant factor to determine the anilinolysis rates of $\mathrm{R}_{1} \mathrm{R}_{2} \mathrm{P}(=\mathrm{L}) \mathrm{Cl}$ in $\mathrm{MeCN}$ is the degree of steric hindrance, since the anilinolysis rates are inversely proportional to the size of the two ligands $\left(\sum E_{\mathrm{S}}\right)$. The steric effects of the two ligands $\left(\mathrm{R}_{1}\right.$ and $\left.\mathrm{R}_{2}\right)$ on the anilinolysis rates of $\mathrm{P}=\mathrm{O}$ 
Table 3. Second-Order Rate Constants $\left(k_{\mathrm{Py}}\right.$ and $\left.k_{\mathrm{An}} \times 10^{3} / \mathrm{M}^{-1} \mathrm{~s}^{-1}\right)$ of the Pyridinolysis $\left(\mathrm{C}_{5} \mathrm{H}_{5} \mathrm{~N}\right)$ at $35.0^{\circ} \mathrm{C}$ and Anilinolysis $\left(\mathrm{C}_{6} \mathrm{H}_{5} \mathrm{NH}_{2}\right)$ at 55.0 ${ }^{\circ} \mathrm{C}$, and Rate Ratios $\left[k_{\mathrm{Py}}\left(35.0^{\circ} \mathrm{C}\right) / k_{\mathrm{An}}\left(55.0^{\circ} \mathrm{C}\right)\right]$ of Ten $\mathrm{R}_{1} \mathrm{R}_{2} \mathrm{P}(=\mathrm{O}$ or $\mathrm{S})$ Cl-type in $\mathrm{MeCN}$

\begin{tabular}{ccccccc}
\hline sub. & $\mathrm{R}_{1}$ & $\mathrm{R}_{2}$ & $\begin{array}{c}k_{\mathrm{Py}} \times 10^{3} \\
\left(35.0{ }^{\circ} \mathrm{C}\right)\end{array}$ & $\begin{array}{c}k_{\mathrm{An}} \times 10^{3} \\
\left(55.0{ }^{\circ} \mathrm{C}\right)\end{array}$ & $\begin{array}{c}k_{\mathrm{Py}}\left(35.0^{\circ} \mathrm{C}\right) / \\
k_{\mathrm{An}}\left(55.0{ }^{\circ} \mathrm{C}\right)\end{array}$ & ref. \\
\hline $\mathbf{1 0}$ & $\mathrm{Me}$ & $\mathrm{Me}$ & 102,000 & 7,820 & 13 & $1 \mathrm{~h},{ }^{a} 1 \mathrm{r}^{b}$ \\
$\mathbf{2 O}$ & $\mathrm{Et}$ & $\mathrm{Et}$ & 127 & 189 & 0.67 & this work, $1 \mathrm{u}$ \\
$\mathbf{3 O}$ & $\mathrm{MeO}$ & $\mathrm{MeO}$ & 64.7 & 4.28 & 15 & $1 \mathrm{~g}, 1 \mathrm{p}$ \\
$\mathbf{4 O}$ & $\mathrm{EtO}$ & $\mathrm{EtO}$ & 52.8 & 2.82 & 19 & $1 \mathrm{~g}, 1 \mathrm{p}$ \\
$\mathbf{5 O}$ & $\mathrm{Ph}$ & $\mathrm{Ph}$ & 54.6 & 1.73 & 32 & $1 \mathrm{~d}, 1 \mathrm{~m}$ \\
$\mathbf{7 O}$ & $\mathrm{PhO}$ & $\mathrm{PhO}$ & 266 & 0.891 & 299 & $1 \mathrm{a}, 1 \mathrm{j}$ \\
$\mathbf{1 S}$ & $\mathrm{Me}$ & $\mathrm{Me}$ & 0.744 & 9.79 & 0.076 & $1 \mathrm{~h}, 1 \mathrm{~s}$ \\
$\mathbf{3 S}$ & $\mathrm{MeO}$ & $\mathrm{MeO}$ & 1.54 & 1.09 & 1.4 & $1 \mathrm{~g}, 1 \mathrm{p}$ \\
$\mathbf{4 S}$ & $\mathrm{EtO}$ & $\mathrm{EtO}$ & 1.19 & 0.512 & 2.3 & $1 \mathrm{~g}, 1 \mathrm{p}$ \\
$\mathbf{5 S}$ & $\mathrm{Ph}$ & $\mathrm{Ph}$ & 1.83 & 0.601 & 3.0 & $1 \mathrm{~d}, 1 \mathrm{n}$ \\
\hline
\end{tabular}

${ }^{a}$ Pyridinolysis. ${ }^{b}$ Anilinolysis.

are much greater than those of $\mathrm{P}=\mathrm{S}$ systems: $k_{\mathrm{An}}(\mathbf{1 0}$ with two small Me $) / k_{\mathrm{An}}(5 \mathrm{O}$ with two large $\mathrm{Ph})=4,520$ for $\mathrm{P}=\mathrm{O}$, while $k_{\mathrm{An}}(1 \mathrm{~S}$ with two small $\mathrm{Me}) / k_{\mathrm{An}}(5 \mathrm{~S}$ with two large $\mathrm{Ph})=16$ for $\mathrm{P}=\mathrm{S}$ system in $\mathrm{MeCN}$ at $55.0^{\circ} \mathrm{C}$. The approach of the aniline nucleophile to the reaction center $P$ should cause extensive steric hindrance when the attacking and leaving groups occupy apical positions in a TBP-5C TS of a backside attack, because of not only a relatively large size of the aniline nucleophile, but also the orientation restriction of the attacking aniline. The lone pair of the amino nitrogen is $\mathrm{sp}^{3}$-type, thus the angle of $\mathrm{C}(\alpha$-carbon of phenyl ring)-N (amino nitrogen)-P (reaction center of substrate) would be $>109.5^{\circ}$ in the TS. The degree of steric hindrance would thus be greater as the ligands of $R_{1}$ and $R_{2}$ become bulkier in the TS. In contrast, the pyridine ring, located more or less parallel to the attacking axis in the TBP-5C TS, would experience much less steric congestion compared to the phenyl ring of the aniline.

The pyridinolysis rate is usually rather faster than the anilinolysis rate for both $\mathrm{P}=\mathrm{O}$ and $\mathrm{P}=\mathrm{S}$ systems (except for $1 \mathrm{~S}$ ), ${ }^{10}$ even taking into account the greater basicity of pyridine than aniline $\left[\mathrm{p} K_{\mathrm{a}}(\right.$ aniline $)=10.56$ and $\mathrm{p} K_{\mathrm{a}}($ pyridine $)=12.33$ in $\mathrm{MeCN} ;{ }^{11} \mathrm{p} K_{\mathrm{a}}$ (aniline) $=4.60^{12}$ and $\mathrm{p} K_{\mathrm{a}}$ (pyridine) $=5.17$ in water at $\left.25.0{ }^{\circ} \mathrm{C}\right]$. The rate ratio of $k_{\text {Py }}\left(35.0{ }^{\circ} \mathrm{C}\right) / k_{\text {An }}\left(55.0{ }^{\circ} \mathrm{C}\right)$ increases as the size of the two ligands increases for both $\mathrm{P}=\mathrm{O}$ and $\mathrm{P}=\mathrm{S}$ system. However, the rate ratios for $\mathrm{P}=\mathrm{O}$ are much greater than those for $\mathrm{P}=\mathrm{S}$ systems.

In summary, the pyridinolysis of diethyl phosphinic chloride (20) is investigated kinetically in acetonitrile at $45.0{ }^{\circ} \mathrm{C}$. The authors propose a concerted mechanism with greater fraction of a frontside attack than that of a backside attack for the pyridinolysis of 2O. The pyridinolyses of eleven $\mathrm{R}_{1} \mathrm{R}_{2} \mathrm{P}(=\mathrm{O}$ or $\mathrm{S}) \mathrm{Cl}$ type substrates in $\mathrm{MeCN}$ (eq 1) are reviewed to obtain systematic information on phosphoryl transfer reaction mechanism. The pyridinolysis rates of $\mathrm{R}_{1} \mathrm{R}_{2} \mathrm{P}(=\mathrm{O}$ or $\mathrm{S})$ Cl-type substrates are not dependent upon one dominant factor but on many factors, while the anilinolysis rates of $\mathrm{R}_{1} \mathrm{R}_{2} \mathrm{P}(=\mathrm{O}$ or $\mathrm{S}) \mathrm{Cl}$-type substrates are predominantly dependent upon the steric effects of two ligands, $R_{1}$ and $R_{2}$.

\section{Experimental Section}

Materals. GR grade diethyl phosphinic chloride (2O) (min 97\%) was used without further purification. GR grade pyridines were used without further purification. HPLC grade acetonitrile (less than $0.005 \%$ water content) was used without further purification.

Kinetic Procedure. Conductometric rate measurements were carried out using self-made computer-aided automatic A/D converter conductivity bridges. The pseudo-first-order rate constants $\left(k_{\text {obsd }}\right)$ were determined as previously described ${ }^{1 \text { a-i }}$ using large excesses of nucleophiles, $[2 \mathrm{O}]=0.001 \mathrm{M}$ and $\left[\mathrm{XC}_{5} \mathrm{H}_{4} \mathrm{~N}\right]=$ $0.01-0.08 \mathrm{M}$. Each pseudo-first-order rate constants value $\left(k_{\mathrm{obsd}}\right)$ was averaged obtained from more than three runs, which were reproducible within $\pm 3 \%$.

Product Analysis. Diethyl phosphinic chloride was reacted with excess pyridine for more than 15 half-lives at $45.0{ }^{\circ} \mathrm{C}$ in acetonitrile. The insoluble products were washed several times with diethyl ether and isolated. The solvent was removed under reduced pressure. Analytical data of the products gave the following results:

$\left(\mathbf{C}_{2} \mathbf{H}_{5}\right)_{2} \mathbf{P}(=\mathbf{O}) \mathbf{N}^{+} \mathbf{C}_{5} \mathbf{H}_{5} \mathbf{C l}^{-}$. White gummy liquid; ${ }^{1} \mathrm{H}$ NMR $\left(400 \mathrm{MHz}, \mathrm{CDCl}_{3}\right) \delta 1.10,1.12,1.14,1.15,1.17,1.19(6 \mathrm{H}, \mathrm{m}$, $\left.\mathrm{CH}_{3}\right), 1.72,1.74,1.75,1.77\left(4 \mathrm{H}, \mathrm{m}, \mathrm{CH}_{2}\right), 7.26,7.98,8.00,8.01$, 8.02, 8.47, 8.91, 8.92, 8.93 (5H, m, pyridine) ${ }^{13} \mathrm{C}$ NMR (100 $\left.\mathrm{MHz}, \mathrm{CDCl}_{3}\right) \delta 5.64,5.69\left(\mathrm{CH}_{3}\right), 20.41,21.34\left(\mathrm{CH}_{2}\right), 127.11$, 141.18, 145.57, $149.45(\mathrm{C}=\mathrm{C}$, pyridine $) ;{ }^{31} \mathrm{P} \mathrm{NMR}(162 \mathrm{MHz}$, $\left.\mathrm{CDCl}_{3}\right) \delta 67.75(1 \mathrm{P}, \mathrm{s}, \mathrm{P}=\mathrm{O}) ; \mathrm{m} / z, 217\left(\mathrm{M}^{+}\right)$; Anal. Calcd for $\mathrm{C}_{9} \mathrm{H}_{15}$ CINOP: C, 49.21; H, 6.88; N, 6.38. Found: C, 49.15; H, $7.05 ; \mathrm{N}, 6.52$.

Acknowledgments. This work was supported by Inha University Research Grant.

\section{References and Notes}

1. Pyridinolyses: (a) Guha, A. K.; Lee, H. W.; Lee, I. J. Org. Chem. 2000, 65, 12. (b) Lee, H. W.; Guha, A. K.; Kim, C. K.; Lee, I. J. Org. Chem. 2002, 67, 2215. (c) Adhikary, K. K.; Lee, H. W.; Lee, I. Bull. Korean Chem. Soc. 2003, 24, 1135. (d) Hoque, M. E. U.; Dey, N. K.; Guha, A. K.; Kim, C. K.; Lee, B. S.; Lee, H. W. Bull. Korean Chem. Soc. 2007, 28, 1797. (e) Adhikary, K. K.; Lumbiny, B. J.; Kim, C. K.; Lee, H. W. Bull. Korean Chem. Soc. 2008, 29 , 851. (f) Lumbiny, B. J.; Adhikary, K. K.; Lee, B. S.; Lee, H. W. Bull. Korean Chem. Soc. 2008, 29, 1769. (g) Dey, N. K.; Hoque, M. E. U.; Kim, C. K.; Lee, H. W. J. Phys. Org. Chem. 2010, 23, 1022. (h) Dey, N. K.; Adhikary, K. K.; Kim, C. K.; Lee, H. W. Bull. Korean Chem. Soc. 2010, 31, 3856. (i) Guha, A. K.; Kim, C. K.; Lee, H. W. J. Phys. Org. Chem. DOI.10.1002/poc.1788. Anilinolyses: (j) Guha, A. K.; Lee, H. W.; Lee, I. J. Chem. Soc., Perkin Trans. 2 1999, 765. (k) Lee, H. W.; Guha, A. K.; Lee, I. Int. J. Chem. Kinet. 2002, 34, 632. (1) Hoque, M. E. U.; Dey, S.; Guha, A. K.; Kim, C. K.; Lee, B. S.; Lee, H. W. J. Org. Chem. 2007, 72, 5493. (m) Hoque, M. E. U.; Lee, H. W. Bull. Korean Chem. Soc. 2007, 28, 936. (n) Dey, N. K.; Han, I. S.; Lee, H. W. Bull. Korean Chem. Soc. 2007, 28, 2003. (o) Hoque, M. E. U.; Dey, N. K.; Kim, C. K.; Lee, B. S.; Lee, H. W. Org. Biomol. Chem. 2007, 5, 3944. (p) Dey, N. K.; Hoque, M. E. U.; Kim, C. K.; Lee, B. S.; Lee, H. W. J. Phys. Org. Chem. 2008, 21, 544. (q) Lumbiny, B. J.; Lee, H. W. Bull. Korean Chem. Soc. 2008, 29, 2065. (r) Dey, N. K.; Hoque, M. E. U.; Kim, C. K.; Lee, B. S.; Lee, H. W. J. Phys. Org. Chem. 2009, 22, 425. (s) Dey, N. K.; Kim, C. K.; Lee, H. W. Bull. Korean Chem. Soc. 2009, 30, 975. (t) Hoque, M. E. U.; Guha, A. 
K.; Kim, C. K.; Lee, B. S.; Lee, H. W. Org. Biomol. Chem. 2009, 7, 2919. (u) Dey, N. K.; Lee, H. W. Bull. Korean Chem. Soc. 2010, 31, 1403. (v) Dey, N. K.; Kim, C. K.; Lee, H. W. Org. Biomol. Chem. 2011, 9, 717. Theoretical: (w) Lee, I.; Kim, C. K.; Li, H. G.; Sohn, C. K.; Kim, C. K.; Lee, H. W.; Lee, B. S. J. Am. Chem. Soc. 2000, 122, 11162.

2. (a) Fischer, A.; Galloway, W. J.; Vaughan, J. J. Chem. Soc. 1964, 3591. (b) Dean, J. A. Handbook of Organic Chemistry; McGrawHill: New York, 1987; Chapter 8.

3. (a) Lee, I.; Kim, C. K.; Han, I. S.; Lee, H. W.; Kim, W. K.; Kim, Y. B. J. Phys. Chem. B 1999, 103, 7302. (b) Coetzee, J. F. Prog. Phys. Org. Chem. 1967, 4, 45.

4. Charton, M. Prog. Phys. Org. Chem. 1987, 16, 287.

5. Taft, R. W. Steric Effect in Organic Chemistry; Newman, M. S., Ed.; Wiley: New York, 1956; Chapter 3

6. (a) Lee, I. Chem. Soc. Rev. 1990, 19, 317. (b) Lee, I. Adv. Phys. Org. Chem. 1992, 27, 57. (c) Lee, I.; Lee, H. W. Collect. Czech. Chem. Commun. 1999, 64, 1529.

7. (a) Hondal, R. J.; Bruzik, K. S.; Zhao, Z.; Tsai, M. D. J. Am. Chem. Soc. 1997, 119, 5477. (b) Holtz, K. M.; Catrina, I. E.; Hengge, A.
C.; Kantrowitz, E. R. Biochemistry 2000, 39, 9451. (c) Omakor, J. E.; Onyido, I.; vanLoon, G. W.; Buncel, E. J. Chem. Soc., Perkin Trans. 2 2001, 324. (d) Gregersen, B. A.; Lopez, X.; York, D. M. J. Am. Chem. Soc. 2003, 125, 7178. (e) Onyido, I.; Swierczek, K.; Purcell, J.; Hengge, A. C. J. Am. Chem. Soc. 2005, 127, 7703. 324. (f) Liu, Y.; Gregersen, B. A.; Hengge, A. C.; York, D. M. Biochemistry 2006, 45, 10043.

8. The $\mathrm{P}=\mathrm{S}$ systems show more significant substituent effects of the nucleophiles compared to the $\mathrm{P}=\mathrm{O}$ systems

9. (a) Rowell, R.; Gorenstein, D. G. J. Am. Chem. Soc. 1981, 103, 5894. (b) Perozzi, E. F.; Martin, J. C.; Paul, I. C. J. Am. Chem. Soc. 1975, 96, 6735. (c) Ramirez, F. Acc. Chem. Res. 1968, 1, 168.

10. Note that the reaction temperatures of pyridinolysis $\left(\mathrm{C}_{5} \mathrm{H}_{5} \mathrm{~N}\right)$ and anilinolysis $\left(\mathrm{C}_{6} \mathrm{H}_{5} \mathrm{NH}_{2}\right)$ are 35.0 and $55.0{ }^{\circ} \mathrm{C}$, respectively, and that the substituent effects of the nucleophiles are not considered.

11. Coetzee, J. F.; Padmanabhan, G. R. J. Am. Chem. Soc. 1965, 87, 5005.

12. Streitwieser, A., Jr.; Heathcock, C. H.; Kosower, E. M. Introduction to Organic Chemistry, 4th ed.; Macmillan Publishing Co.: New York, 1992; p. 735. 